\title{
A SOCIOLOGICAL ASSESSMENT OF CONJUGAL CONFLICT
}

\author{
Francesco Giudici, Eric Widmer, and Paolo Ghisletta
}

Beyond psychological explanations of conjugal conflict, associated with personality mismatches and micro-relational dimensions (Coleman et al., 1980), some sociological explanations of conjugal conflict have been proposed (Birtchell, 1986; Hochschild, 1989; Olson, 2000; Popenoe, 1996). Although conjugal conflict and divorce are major features of contemporary societies, little empirical quantitative research has been done to put those explanations to the test. This paper tests the impact of three dimensions of partnerships on conjugal conflict: division of household labor, conjugal individualism, and conjugal closure.

\section{Factors of conjugal conflict in a sociological perspective}

By far, the most frequently studied factor of conjugal conflict in a sociological perspective is the "division of household labor". Despite significant progress toward greater gender equality in Western societies (Amato and Booth, 1995; Xu and Lai, 2004), researchers continue to find persistent inequalities between men and women concerning their responsibilities for household tasks (Hochschild, 1989; Perry-Jenkis and Folk, 1994; Thompson and Walker, 1989). Several researchers have addressed the impact of an unequal division of household labor on conjugal satisfaction (Perry-Jenkis and Folk, 1994; Pina and Bengston, 1993; Suitor, 1991), conjugal conflict (Kluwer et al., 1996; Stohs, 2000), and divorce proneness (Frisco and Williams, 2003). Some researchers found that an unequal division of household labor predicts conjugal conflict (Kluwer et al., 1996; Ferree, 1991; Mederer, 1993; Perry-Jenkis and Folk, 1994; Stohs, 2000; Thompson, 1991). However, other results suggested that it is not inequality per se that led to conjugal conflict, but its perception as unfair (Major, 1993).

A second and less investigated issue in family sociology involves the consequences of "conjugal individualism" on conjugal conflict. A tension has opposed for decades the fusional ideals of conjugality, in which "sharing" is considered to be the key to happiness, to the individualistic ideas of the "self", in which clearly establishing one's personal rights and autonomy is interpreted as a sign of psychological maturity and evidence of relationship success (Mansfield and Collard, 1988). Conjugal individualism is also a matter of similar or dissimilar life styles and values in a couple. Individualistic relationships value diversity more, and partners feel more free to develop and maintain their personal interests, practices and ideas; therefore, they are more centered on personal achievement (Reiss and Lee, 1988). In its most extreme version, conjugal individualism negates any obligation towards one's spouse or partner except that of an open and honest communication (Bellah et al., 1986). 
Few researches have empirically analyzed the effects of conjugal individualism on relationship quality. Some scholars have argued that fusion and shared activities promote relationship stability (Askham, 1984; Dion and Dion, 1991; Le, 2005; Duck et al., 1991) and sexual or conjugal satisfaction (Lewis and Spanier, 1979; Orthner, 1975; Patton and Waring, 1985). Gohm et al. (1998) conducted a cross-cultural comparison and found that an individualistic culture is associated with higher rates of divorce and marital conflict. Other researchers have reported that divergences in politics, religion, and social behaviors are generally associated with a decrease in conjugal quality (Lehrer and Chiswick, 1993). Claxton and Perry-Jenkins (2008) showed that couples who participate in fewer shared leisure activities develop conflict more frequently. On the contrary, some researchers show that spouses who emphasize autonomy in their relationships have a greater chance of forming a stable and satisfactory partnership (Birtchell, 1986; Askham, 1984). Despite its theoretical importance, which is acknowledged by prominent scholars (Giddens, 1992; Popenoe, 1996; Stacey, 1996), there is a paucity of empirical research on the impact of conjugal individualism on relationship quality. Based on the existing research, it is unclear whether the quest for autonomy in intimate relationships is detrimental or beneficial to couple interactions (De Singly, 1996).

A third factor, the family closure, has been stressed as a determinant of conjugal conflict (Widmer et al., 2006a). Conjugal relationships do not exist in a vacuum. Scholars have emphasized how important it is to take into account the social environment in which these relationships are embedded (Bott, 1957; Burger and Milardo, 1995; Milardo and Allan, 2000). The relationship between couples and their environment has served as the foundation for various family typologies based on clinical populations. Inspired by the works of Kantor and Lehr (1975), who made the distinction between open and closed family functioning, Olson (2000) considered adaptability to be a main condition of conjugal functioning. Families that are either rigid or chaotic in their internal relationships and in their interactions with the environment show the greatest prevalence of problems and conflicts, whereas open families tend to deal with their conflicts and problems more effectively. From this perspective, conjugal closure might decrease the effects of conjugal conflict, rather than increase them, because it prevents further interference from the environment in the couple's relationship. However, the evidence supporting the impact of conjugal closure on conjugal conflict remains scarce.

Overall, the literature review suggests that a gendered division of household labor, conjugal individualism and family closure are factors of conjugal conflict. In most cases, results that considered these factors were based on clinical (Olson, 2000) or non-representative samples (Le, 2005), with non longitudinal design. Moreover, there is no study that considers the three dimensions simultaneously. In contrast, the purpose of the present study is to measure their impact on conjugal conflict using a large, representative and longitudinal sample of married and unmarried couples. 
Method

Sample

The data were drawn from the study "Social Stratification, Cohesion and Conflict in Contemporary Families", a large and representative two-wave survey of married and unmarried heterosexual couples living in Switzerland (Widmer et al., 2003). The first wave of data collection was conducted in 1999, whereas the second wave took place in 2004. The study's primary goal was to examine how conjugal functioning was embedded in social statuses and life stages. Participants were randomly selected using a non-proportional stratified design from the three major language areas of Switzerland. The questionnaire was administered via a computer-assisted telephone survey.

In order to be included in the sample, participants had to live in Switzerland and cohabited for at least one year. In addition, the younger partner had to be at least 20 years of age, whereas the older partner had to be less than 70 years of age. Responses were weighted according to the population size of each linguistic region. In Wave 1, 1,534 couples were surveyed; therefore, 3,068 interviews were conducted (see Widmer et al., 2003; and Widmer et al., 2006a). During Wave 2 in 2004, there were 979 original participants ( $70 \%$ of the participants from the Wave 1$)$. Due to a limited research budget, only women were interviewed in this wave. To promote coherence in the research design, we decided to include only the women's answers also from Wave 1 in the analyses. On all major dimensions of family life considered, the reports of the partners were relatively consistent based on the results of analyses performed on the data from Wave 1 (Widmer et al., 2003; and Widmer et al., 2006a). We include all the available information for the first wave (we used Full-Information Maximum Likelihood as suggested by Wothke, 1998), and we exclude from the analysis data from female participants who were no longer with the same partner in Wave 2. Note that there were no selection effects on Wave 2. Women who took part in Wave 2 did not have higher levels of conjugal conflict in Wave 1 compared to women who did not follow-up the study. However, women with more than one child were overrepresented in Wave 2.

\section{Measures}

Dimensions of conjugal functioning were measured in Wave 1 only. "Division of household labor" between partners or spouses was the only latent factor measured as a proxy for gender inequalities by two first order factors: the amount of time devoted to household tasks during workdays and weekends (answers ranged from 1 "less than an hour" to 5 "seven or more hours") and the kind of division of household tasks completed with the partner, such as cooking, laundry, ironing, dishwashing, cleaning, and shopping (answers included 1 "less than one quarter", 2 "one fourth", 3 "one half", 4 "three fourth", 5 "almost all"). Higher scores indicate a greater amount of time devoted to household tasks for women and greater inequalities in domestic household labor. 
The extent of conjugal closure was measured with three items associated with the degree of openness that couples have in relation to their community environment: "You keep yourself informed daily about the economic and political life", "You are not very attracted by the customs of other countries", and "You stay informed about your country and region". Responses ranged from 1 "true" to 4 "not at all true". Items were recoded, with higher scores indicating a higher degree of closure throughout the environment. In order to measure the extent of conjugal individualism of the partners, we chose seven items with the same range of responses. These items were: "You spend most of your evenings with your partner", "Concerning music, books or films, you and your partner have very similar taste", "All financial entries of the household belong equally to you and your partner", "Concerning politics and religion, you and your partner have similar ideas", "In your couple, you need a large amount of autonomy", "You sacrifice some personal activities to stay with your partner", and "When you see friends, it's more often with your partner". Higher scores indicated higher conjugal individualism.

Conjugal conflict perceived by women was measured in Wave 1 and in Wave 2 with four items. The first item included five communicational and relational problems that couples can have as a dichotomous variable (responses ranged from 1 "no problem" to 6 "five problems"). The second item focused on the severity of open arguments (responses ranged from 1 "no open arguments" to 4 "severe arguments"). The third item asked participants to rate how satisfied they were with their conjugal life (responses ranged from 1 "always satisfied" to 5 "never satisfied"). Finally, the fourth item measured the efficacy of participants' coping strategies (responses were 1 "bad", 2 "low", 3 "average", and 4 "good coping strategies"). For further details on these data see Widmer et al. (2003). An examination of the means in descriptive statistics for the items shows that women do the majority of household tasks. Further, conjugal individualism is relatively low on all but a few items (i.e., common tastes and feeling of autonomy).

Because levels of conjugal conflict and conjugal quality vary across conjugal life (Aldous, 1996; Umberson et al., 2005), it is necessary to control for the effect of "family life stages". Therefore, we distinguished couples which were childless ( $\mathrm{n}=$ $226)$, couples which had children currently living in the home ( $\mathrm{n}=943)$, and couples whose children already left the parental home $(n=307)$ which is used as the reference category in the empirical analyses. When either skewness estimates are less than -3 or greater than 3 or kurtosis estimates are less than -7 or greater than 7 , a distribution deviates highly from normality (Kline, 1998). Given that the scales under investigation show skewness and kurtosis estimates relatively close to 0 , which corresponds to a normal distribution, we used the maximum likelihood algorithm to estimate all of the parameters of the structural equation modeling (SEM).

1 Some other items were excluded from the analysis following the factor analysis presented later in the results section. 
Analyses

SEM was first used to test the validity of the three factors measuring division of household labor, conjugal individualism and closure. In SEM, two kinds of models are distinguished: the measurement model, which represents the unmeasured constructs via the measured items, and the structural model, which represents the associations between the constructs. Therefore, a typical SEM is composed of several measurement models and one structural model. It is advisable to first test all measurement models before proceeding with the assessment of the structural model (Byrne, 2001). To test the measurement models, we computed a confirmatory factor analysis (CFA) on each set of items. The CFA is fundamental before testing a general model that focuses on the relationships between the various dimensions to exclude items with poor factor loadings and high residual variances that are not indicative of the general construct (Byrne, 2001).

In the second stage, we tested the structural model with the relationships among factors of conjugal functioning, family life stages and conjugal conflict for the whole sample. Amos 18.0 software (Arbuckle and Wothke, 1999) was used to test all of the SEMs. This model relied on the longitudinal nature of the study to infer the effects of the predictors assessed in the first wave on conflict assessed in the first and second waves.

\section{Results}

Measurement models. The first set of analyses involved CFAs that assessed the best factorial representation of each explanatory dimension in Wave 1 and conflict as measured in Waves 1 and 2 (Byrne, 2001). To assess a model's capacity to reproduce the data structure, we relied on commonly used fit indices: the chi-square and its associated degrees of freedom and the root mean square error of approximation (RMSEA). A model is considered to be adjusted to the data if its RMSEA is less than 0.08 (Hu and Bentler, 1999).

The results of the CFAs showed that the six measurement models fitted the data well, except for closure, which had a moderate fit to the data (see table 1). Those fit indexes indicated that the items indeed measure our distinct factors. Moreover, this first step of the analysis enabled us to select the items that were more representative of every construct. For example, for closure, we excluded three items pertaining to partners' habits with friends inside and outside of the house. Because the three dimensions of conjugal individualism, closure, and division of household labor were allowed to correlate in the final SEM, we also conducted a CFA on these three dimensions together (see table 1). We found that this model fitted the data well. Furthermore, results indicated that the three dimensions only weakly covary (i.e., no multicollinearity between them). This first set of results confirmed that division of household labor, conjugal closure, and conjugal individualism are three independent dimensions of conjugal life, as outlined in Widmer et al. (2006a). 
Table 1 Fit Indices of the measurement models of each conjugal dimension and of conflict

\begin{tabular}{|c|c|}
\hline Model & Fit indices \\
\hline Measurement — individualism & $\begin{array}{l}\left.\chi_{(\mathrm{df}}^{2}=14, \mathrm{~N}=1534\right)=86.566 \\
\quad \mathrm{RMSEA}=0.058\end{array}$ \\
\hline Measurement - closure & $\begin{array}{l}\chi^{2}(\mathrm{df}=1, \mathrm{~N}=1534)=86.557 \\
\quad \mathrm{RMSEA}=0.236\end{array}$ \\
\hline Measurement — division of labor & $\begin{array}{l}\chi_{(d f=4, N=1534)}^{2}=5.847 \\
\quad \text { RMSEA }=0.017\end{array}$ \\
\hline $\begin{array}{l}\text { Confirmatory factor analysis with three dimensions of } \\
\text { conjugal interaction }\end{array}$ & $\begin{array}{l}\chi^{2}(\mathrm{df}=88, \mathrm{~N}=1534)=499.970 \\
\quad \text { RMSEA }=0.055\end{array}$ \\
\hline Measurement - conflict Wave 1 & $\begin{array}{l}\left.\chi_{(d f}^{2}=2, N=1534\right)=85,566 \\
\quad R M S E A=0.058\end{array}$ \\
\hline Measurement - conflict Wave 2 & $\begin{array}{l}\chi_{(d f=2, N=982)}^{2}=11.998 \\
\quad R M S E A=0.057\end{array}$ \\
\hline
\end{tabular}

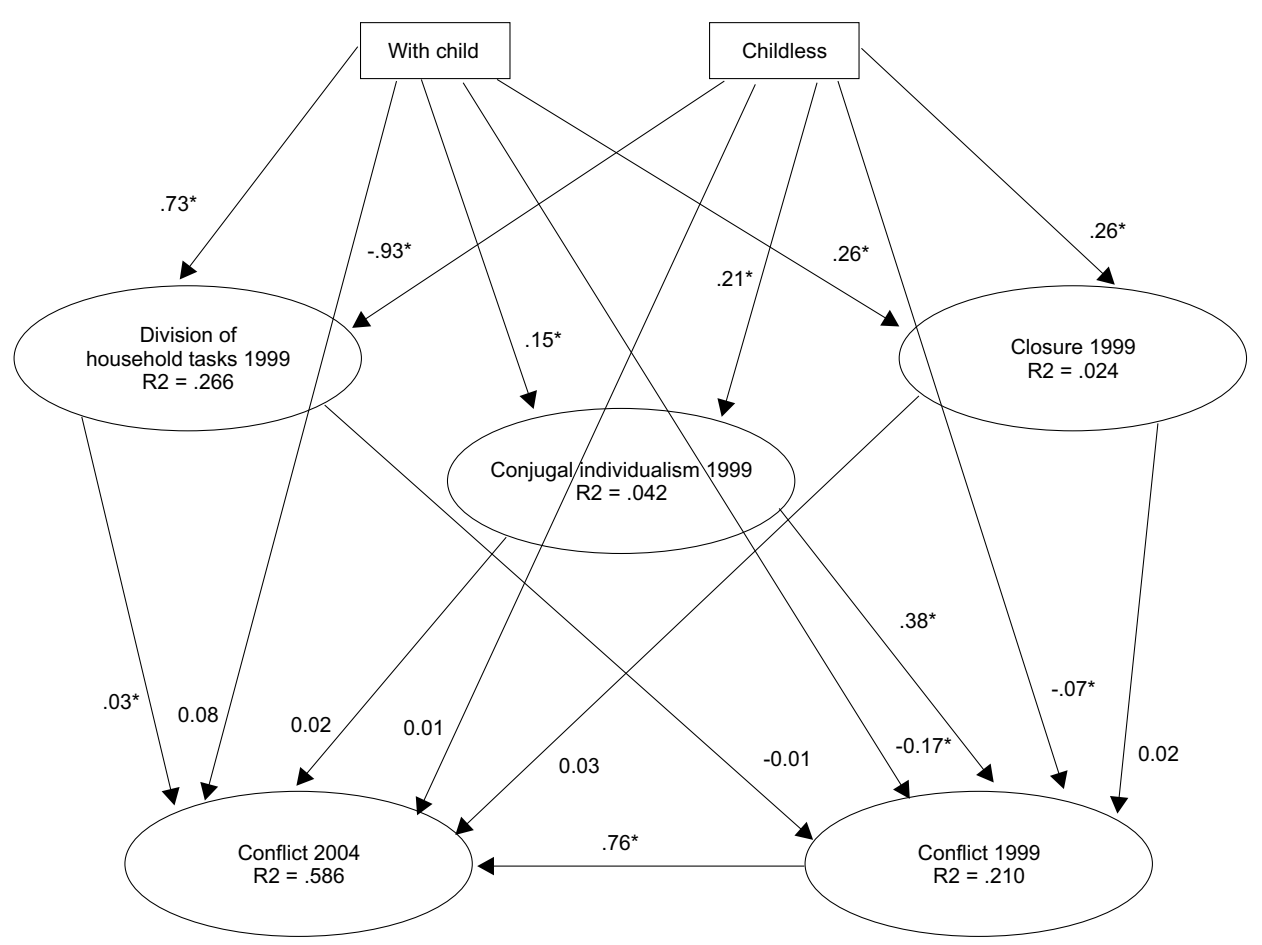

Figure 1 Structural model 1 (unstandardized estimates; $n=1534$ ) of the impact of family life stages (with children and childless) on closure, conjugal individualism, and division of household labor in Wave 1 , and their impact on conflict in Wave 1 and Wave 2

Note: * indicates parameters that are significant at the 0.01 level. 
Table 2 Parameter estimates (and standard errors) of the measurement models for structural model 1, represented in figure 1

\begin{tabular}{|c|c|c|c|}
\hline & Variables & Residual variances & Factor loadings \\
\hline \multicolumn{4}{|c|}{ Individualism } \\
\hline & $\begin{array}{c}\text { Evenings } \\
\text { Politics and religion } \\
\text { Friends } \\
\text { Money } \\
\text { Activities without partner } \\
\text { Autonomy } \\
\text { Tastes }\end{array}$ & $\begin{array}{l}.559(.026)^{\star} \\
.485(.019)^{\star} \\
.582(.024)^{\star} \\
.416(.016)^{\star} \\
.942(.041)^{\star} \\
.753(.029)^{\star} \\
1.055(.039)^{\star}\end{array}$ & $\begin{array}{c}1.000 \\
.616(.094)^{\star} \\
.789(.111)^{\star} \\
.474(.081)^{\star} \\
1.110(.149)^{\star} \\
.628(.108)^{\star} \\
.439(.114)^{\star}\end{array}$ \\
\hline \multicolumn{4}{|c|}{ Division of household labor } \\
\hline Time & $\begin{array}{l}\text { Hours of labor (week) } \\
\text { Hours of labor (weekend) }\end{array}$ & $\begin{array}{l}.145(.057)^{*} \\
.899(.044)^{*}\end{array}$ & $\begin{array}{c}1.000 \\
.712(.037)^{\star}\end{array}$ \\
\hline Kind & $\begin{array}{l}\text { Meal/shop } \\
\text { Clean } \\
\text { Clothes }\end{array}$ & $\begin{array}{l}.557(.026)^{\star} \\
.342(.032)^{\star} \\
.382(.017)^{*}\end{array}$ & $\begin{array}{c}1.379(0.113)^{\star} \\
1.901(0.161)^{*} \\
1.000\end{array}$ \\
\hline \multicolumn{4}{|l|}{ Closure } \\
\hline & $\begin{array}{c}\text { Informed (politics/economy) } \\
\text { Other cultures } \\
\text { Informed (canton/village) }\end{array}$ & $\begin{array}{l}.460(.082)^{*} \\
.928(.035)^{\star} \\
.675(.053)^{*}\end{array}$ & $\begin{array}{c}1.000 \\
.308(.057)^{\star} \\
.769(.124)^{\star}\end{array}$ \\
\hline \multicolumn{4}{|c|}{ Conflict Wave 1} \\
\hline & $\begin{array}{l}\text { Number of problems } \\
\text { Type of conflict } \\
\text { Couple evaluation } \\
\text { Coping strategies }\end{array}$ & $\begin{array}{l}.625(.060)^{\star} \\
.462(.017)^{\star} \\
.306(.013)^{*} \\
.334(.016)^{*}\end{array}$ & $\begin{array}{c}1.268(.083)^{\star} \\
1.000 \\
4.192(.256)^{\star} \\
1.713(.108)^{\star}\end{array}$ \\
\hline \multicolumn{4}{|c|}{ Conflict Wave 2} \\
\hline & $\begin{array}{c}\text { Number of problems } \\
\text { Type of conflict } \\
\text { Couple evaluation } \\
\text { Coping strategies }\end{array}$ & $\begin{array}{l}.351(.017)^{\star} \\
.367(.017)^{*} \\
.451(.070)^{\star} \\
1.074(.051)^{\star}\end{array}$ & $\begin{array}{c}1.268(.083)^{*} \\
1.000 \\
4.192(.256)^{\star} \\
1.713(.108)^{\star}\end{array}$ \\
\hline
\end{tabular}

Note: The variables for the factor "division" load on the first-order factors "time" and "type", which themselves load on the second-order factor "division".

$=$ denotes parameters whose value was fixed for identification purpose.

Model fit: $\chi 2(\mathrm{~N}=1534, \mathrm{df}=254)=940.740$, RMSEA $=0.042$.

${ }^{*}$ indicates parameters that are significant at the 0.01 level.

Structural model 1. Figure 1 and table 2 present the structural model, variables' factor loadings and residual variances. Given the total sample size, we chose a cutoff alpha value of 0.01 for significance testing. This model fitted the data well. All factor loadings were highly significant $(p$ values $<0.01)$. The value of some factor loadings had to be fixed to 1 for the purpose of local identification (Bollen, 1989). In order to represent consistently conflict as measured in Wave 1 and Wave 2, we applied the principles of metric invariance to the factor loadings (Meredith, 1964). Specifically, we set the two factors up as a longitudinal factor model (McArdle and Nesselroade, 1994), where the loadings of the factors were invariant and the residual variances of the indicator variables were allowed to correlate over time. This makes sure that conflict as measured in the first and second waves could be compared, given that both relied on the same measurement model. 
Unstandardized estimates in figure 1 show that of division of household labor, conjugal closure, and conjugal individualism measured in the first wave, only conjugal individualism has a significant influence on conflict in Wave 1. Moreover, family life stages are strongly associated with dimensions of conjugal functioning, especially for conjugal individualism (higher in childless couples) and division of household labor (higher in couples with children). Also, the residuals of the three dimensions of conjugal functioning, related between them, do not correlate, meaning that the lack of influence of division of household labor and closure on conflict as measured in the second wave is not related with their associations with conjugal individualism as measured in the first wave.

The no effect of conjugal individualism on conflict in the second wave is explained by the mediation effect of conjugal conflict in Wave 1. Conjugal individualism has a causal effect on conflict in Wave 1, which is strongly related with conflict in Wave 2. Almost $60 \%$ of the variance in conflict in Wave 2 is predicted by conflict in Wave 1 . Note that there is a small but significant effect of division of household labor in Wave 1 on conjugal conflict measured in Wave 2.

\section{Discussion}

Conjugal individualism has a major effect on conjugal conflict. This result supports the hypothesis that couples based on values of autonomy and a prevalence of individual development on the collective dimension of conjugal and family life have a harder time to last over time. Those results contradict statements about the greater stability of couples that emphasize such values in their daily interactions. They suggest that there is a cumulative process by which autonomy fuels conflict that further increases the propensity of partners to live autonomous lives. The result is also consistent with other empirical results pertaining to the stability of conflict in couples over time (Faulkner et al., 2005).

The absence of children in the household increases the extent of conjugal individualism. While controlling for the presence of children, conjugal individualism however maintains its negative influence on conjugal conflict. This indicates that once partners become parents, conjugal individualism becomes a negative factor for conjugal life, which contributes to increase conjugal conflict in a cumulative way (Cowan and Cowan, 2000).

Division of household labor has been thoroughly studied in recent decades but seldom with a longitudinal design. This research shows that it has some impact on conjugal conflict, although not as strong conjugal individualism. Nevertheless, the association between actual division of household labor and its perceived fairness (Major, 1993) could help to understand why so many couples continue to follow a gendered division of tasks while keeping conflict and conjugal dissatisfaction at bay.

With regard to conjugal closure, its lack of impact is striking. One possible explanation involves the various meanings of family closure. Although a high level of openness through social network members and social environment can lead to interference and generate conjugal conflict, a high level of closure can also create 
conjugal conflict (Olson, 2000). Additional research on actual patterns of interactions with friends and relatives is needed before it is possible to reject the hypothesis that conjugal closure is not a factor of conjugal conflict. It might be useful for future research to differentiate a measure of positive closure that limits interference, from a measure of negative closure that limits potential support from social network members (Widmer et al., 2009).

Conjugal individualism directly affects conjugal conflict. Individualism is a relational problem, especially for couples with children. The emphasis on conjugal individualism as a contributor to conflict is supported by explanations given by psychologists and social psychologists, as conjugal individualism is associated with poorer coping strategies and a higher level of depressive symptoms, especially for women (Widmer et al., 2003; Widmer et al., 2006b). The finding of a negative impact of conjugal individualism certainly calls for further research. Additional waves, which include men's interviews as well as women's interviews, are necessary, given that the extent of conjugal individualism and the perception of conflict may vary through time and between partners. Indeed, this research has one important limit: conjugal conflict was measured by responses of women only. Further research should include estimates of conflicts by both men and women, in order to provide a more comprehensive view on the impact.

\section{References}

Aldous, Joan (1996), Family Careers. Rethinking the Developmental Perspective, Thousand Oaks, Sage Publications.

Amato, Paul. R., and Alan Booth (1995), "Changes in gender role attitudes and perceived marital quality", American Sociological Review, 60, pp. 58-66.

Arbuckle, James L., and Werner Wothke (1999), Amos 4.0 User's Guide, Chicago, SmallWaters Corporation.

Askham, Janet (1984), Identity and Stability in Marriage, Cambridge, Cambridge University Press.

Bellah, Robert. N., Richard Madsen, William Sullivan, Ann Swidler, and Steven Tipton (1986), Habits of the Heart, New York, Harper \& Row.

Birtchell, John (1986), “The imperfect attainment of intimacy: a key concept in marital therapy", Journal of Family Therapy, 8, pp. 153-172.

Bollen, Kenneth A. (1989), Structural Equations with Latent Variables, New York, John Wiley and Sons.

Bott, Elisabeth (1957), Family and Social Networks, London, Tavistock.

Burger, Edith, and Robert M. Milardo (1995), “Marital interdependence and social networks", Journal of Social and Personal Relationships, 12, pp. 403-415.

Byrne, Barbara M. (2001), Structural Equation Modeling with AMOS. Basic Concepts, Applications and Programming, Hillsdale, NJ, Lawrence Erlbaum Associates.

Claxton, Amy, and Maureen Perry-Jenkins (2008), “No fun anymore: leisure and marital quality across the transition to parenthood", Journal of Marriage and the Family, 70, pp. 28-43. 
Coleman, Karen H., Maxine L. Weinman, and P. H. Bartholomew (1980), “Factors affecting conjugal violence", The Journal of Psychology, Interdisciplinary and Applied, 105, pp. 197-202.

Cowan, Carolyn P., and Philip A. Cowan (2000), When Partners Become Parents. The Big Life Change for Couples, London, Lawrence Erlbaum Associates.

De Singly, François (1996), Sociologie de la Famille Contemporaine, Paris, Nathan.

Dion, Karen K., and Kenneth L. Dion (1991), "Psychological individualism and romantic love", Journal of Social Behaviour and Personality, 6, pp. 17-33.

Duck, Steve W., Deborah J. Rutt, Margaret Hoy, and Hurst H. Strejc (1991), “Some evident truth about conversations in everyday relationships: all communications are not created equal", Human Communication Research, 18, pp. 228-267.

Faulkner, Rhonda A., Maureen Davey, and Adam Davey (2005), “Gender-related predictors of change in marital satisfaction and marital conflict", The American Journal of Family Therapy, 33, pp. 61-83.

Ferree, Myra M. (1991), “The gender division of labor in two-earner marriages: dimensions of variability and change", Journal of Family Issues, 12, pp. 158-180.

Frisco, Michelle L., and Kristi Williams (2003), "Perceived housework equity, marital happiness and divorce in dual-earner households", Journal of Family Issues, 24, pp. 51-73.

Giddens, Anthony (1992), The Transformation of Intimacy. Sexuality, Love and Eroticism, Cambridge, Polity Press.

Gohm, Carol L., Shigehiro Oishi, Janet Darlington, and Ed Diener (1998), “Culture, parental conflict, parental marital status and the subjective well-being of young adults", Journal of Marriage and the Family, 60, pp. 319-334.

Hochschild, Arlie (1989), The Second Shift, New York, Avon Books.

$\mathrm{Hu}$, Li-Tze, and Peter M. Bentler (1999), “Cutoff criteria for fit indexes in covariance structure analysis: conventional criteria versus new alternatives", Structural Equation Modeling, 6, pp. 1-55.

Kantor, David, and William Lehr (1975), Inside the Family. Toward a Theory of Family Process, San Francisco, Jossey-Bass.

Kline, Rex B. (1998), Structural Equation Modeling, New York, The Guilford Press.

Kluwer, Esther S., Josi Heesink, and Evert Van de Vliert (1996), “Marital conflict about the division of household labor and paid work", Journal of Marriage and the Family, 58, pp. 958-969.

Le, Thao N. (2005), “Narcissism and immature love as mediators of vertical individualism and ludic love style", Journal of Social and Personal Relationships, 22, pp. 543-560.

Lehrer, Evelyn L., and Carmel U. Chiswick (1993), “Religion as a determinant of marital stability", Demography, 30, pp. 385-404.

Lewis, Robert A., and Graham B. Spanier (1979), “Theorizing about the quality and stability of marriage", in W. R. Burr, R. Hill, F. I. Nye, and I. L. Reiss (eds.), Contemporary Theories about the Family, vol. 1, New York, The Free Press, pp. 268-294.

Major, Brenda (1993), "Gender, entitlement and the distribution of family labor", Journal of Social Issues, 49, pp. 141-159.

Mansfield, Penny, and Jean Collard (1988), The Beginning of the Rest of Your Life? A Portrait of the Newly-Wed Marriage, London, Macmillan. 
McArdle, Joseph J., and John R. Nesselroade (1994), “Using multivariate data to structure developmental change", in Stanley H. Cohen, and Hayne W. Reese (eds.), Life-Span Developmental Psychology. Methodological Contributions, Hillsdale, NJ, Lawrence Erlbaum Associates, pp. 223-267.

Mederer, Helen J. (1993), “Division of labor in two-earner homes: task accomplishment versus household management as critical variables in perceptions about family work", Journal of Marriage and the Family, 55, pp. 133-145.

Meredith, William (1964), "Notes on factorial invariance", Psychometrika, 29, pp. 177-185.

Milardo, Robert M., and Graham Allan (2000), "Social networks and marital relationships", in R. M. Milardo, and S. Duck (eds.), Familes as Relationships, New York, Wiley, pp. 117-134.

Olson, David H. (2000), “Circumplex model of marital and family system”, Journal of Family Therapy, 22, pp. 144-167.

Orthner, Dennis K. (1975), “Leisure activity patterns and marital satisfaction over the marital career", Journal of Marriage and the Family, 37, pp. 91-102.

Patton, David, and Edward M. Waring (1985), "Sex and marital intimacy", Journal of Sex and Marital Therapy, 11, pp. 76-184.

Perry-Jenkis, Maureen, and Karen Folk (1994), “Class, couples and conflict: effects of the division of labor on assessment of marriage in dual-earner families", Journal of Marriage and the Family, 56, pp. 165-181.

Pina, Darlene L., and Vern L. Bengston (1993), “The division of household labor and wives happiness: ideology, employment and perceptions of support", Journal of Marriage and the Family, 55, pp. 901-912.

Popenoe, David (1996), "Gender and family change in industrialized countries", Population and Development Review, 22, pp. 373-374.

Reiss, Ira L., and Gary R. Lee (1988), Family Systems in America, fourth edition, Orlando, FL, Harcourt Brace Jovanovich College Publishers.

Stacey, Judith (1996), Brave New Families. Stories of Domestic Upheaval in Late Twentieth Century America, New York, Basic Books.

Stohs, Joanne H. (2000), “Multicultural women's experience of household labor, conflicts and equity", Sex Roles, 42, pp. 339-361.

Suitor, J. Jill (1991), “Marital quality and satisfaction with the division of household labor across the family life cycle", Journal of Marriage and the Family, 53, pp. 221-230.

Thompson, Linda (1991), “Family work: women's sense of fairness", Journal of Family Issues, 12, pp. 181-196.

Thompson, Linda, and Alexis J. Walker (1989), “Gender in families: women and men in marriage, work and parenthood", Journal of Marriage and the Family, 51, pp. 845-871.

Umberson, Debra, Kristi Williams, Daniel A. Powers, Meichu D. Chen, and Anna M. Campbell (2005), "As good as it gets? A life course perspective on marital quality", Social Forces, 84, pp. 493-511.

Widmer, Eric D., Jean Kellerhals, and Reni Levy (2003), Couples Contemporains. Cohésion, Régulation et Conflits. Une Enquête Sociologique, Zürich, Seismo.

Widmer, Eric D., Jean Kellerhals, and Reni Levy R. (2006a), “What pluralization of family relationships? Conflicts, conjugal interaction styles and social milieu", Revue Française de Sociologie, Annual English Selection, 47, pp. 131-156. 
Widmer, Eric D., Jean Kellerhals, and Reni Levy (2006b), “Types of conjugal interactions and conjugal conflict: a longitudinal assessment", European Sociological Review, 22, pp. 79-89.

Widmer Eric D., Francesco Giudici, Jean-Marie LeGoff, and Alexandre Pollien (2009), "From support to control: a configurational perspective on conjugal quality", Journal of Marriage and the Family, 71, pp. 437-448.

Wothke, Werner (1998), "Longitudinal and multi-group modeling with missing data", in T. D. Little, K. U. Schnabel, and J. Baumert (eds.), Modeling Longitudinal and Multiple Group Data. Practical Issues, Applied Approaches and Specific Examples, Mahwah, NJ, Lawrence Erlbaum Associates.

$\mathrm{Xu}$, Xiahoe, and S.-C. Lai (2004), “Gender ideologies, marital roles and marital quality in Taiwan", Journal of Marriage and the Family, 25, pp. 318-355.

Eric Widmer. Department of Sociology, University of Geneva.

E-mail: eric.widmer@unige.ch

Paolo Ghisletta. Faculty of Psychology and Educational Sciences, University of Geneva. E-mail: Paolo.Ghisletta@unige.ch

\section{Resumo/ abstract/ résumé/ resumen}

\section{Uma abordagem sociológica do conflito conjugal}

A explicaçao sociológica do conflito conjugal tem sido muito referida, mas raramente testada empiricamente. Com base num conjunto de dados longitudinais recolhidos em duas fases junto de 1534 mulheres em relações heterossexuais, usámos o modelo de equações estruturais (SEM) para medir o impacto da divisão do trabalho doméstico, do individualismo e do fechamento do casal sobre a probabilidade de conflitos conjugais. Os resultados indicam que o individualismo conjugal tem um grande impacto, a divisão do trabalho doméstico um impacto menor e o fechamento do casal não tem impacto no conflito conjugal. Os resultados são discutidos à luz dos actuais debates sociológicos sobre conjugalidade.

Palavras-chave conflito conjugal, individualismo, divisão do trabalho, fechamento, longitudinal, modelo de equações estruturais.

\section{A sociological assessment of conjugal conflict}

A sociological explanation of conjugal conflict was often stressed but seldom empirically tested. Based on a two-wave longitudinal dataset of 1534 women in heterosexual relationships, we use structural equation modeling (SEM) to measure 
the impact of the division of household labor, individualism and conjugal closure on the likelihood of conjugal conflicts. Results indicate that conjugal individualism has a major impact, division of household labor a minor impact, and conjugal closure no impact, on conjugal conflict. Results are discussed in the light of current sociological debates on partnerships.

Keywords conjugal conflict, individualism, division of labor, closure, longitudinal, structural equation model.

\section{Une approche sociologique du conflit conjugal}

L'explication sociologique du conflit conjugal a souvent été avancée mais rarement testée du point de vue empirique. À partir d'un ensemble de données longitudinales recueillies en deux phases auprès de 1534 femmes vivant en couple hétérosexuel, nous avons utilisé le modèle d'équations structurelles pour mesurer l'impact de la répartition des tâches ménagères, de l'individualisme et de l'isolement du couple sur la probabilité des conflits conjugaux. Les résultats indiquent que l'individualisme conjugal a un grand impact, la répartition des tâches ménagères un impact moindre et l'isolement du couple n'a pas d'impact sur le conflit conjugal. Les résultats sont discutés à la lumière des débats sociologiques actuels sur la conjugalité.

Mots-clés conflit conjugal, individualisme, répartition des tâches ménagères, isolement, longitudinal, modèle d'équations structurelles.

\section{Un abordaje sociológico del conflicto conyugal}

La explicación sociológica del conflicto conyugal ha sido muy referida, pero raramente probada empíricamente. Con base en un conjunto de datos longitudinales recabados en dos etapas, con 1534 mujeres en relaciones heterosexuales, usamos el modelo de ecuaciones estructurales (SEM) para medir el impacto de la división del trabajo doméstico, del individualismo y del cierre de la pareja sobre la probabilidad de conflictos conyugales. Los resultados indican que el individualismo conyugal tiene un gran impacto, la división del trabajo doméstico un impacto menor y el cierre de la pareja no tiene impacto en el conflicto conyugal. Los resultados son discutidos a la luz de los actuales debates sociológicos sobre la vida en pareja.

Palabras clave conflicto conyugal, individualismo, división del trabajo, cierre, longitudinal, modelo de ecuaciones estructurales. 
